\title{
Sustainability of ICT hardware procurement in Switzerland
}

\author{
A status-quo analysis of the public procurement sector
}

\author{
Tobias Welz \\ Institute of Computer Science \\ University of Bern \\ Bern, Switzerland \\ tobias.welz@inf.unibe.ch
}

\author{
Matthias Stuermer \\ Institute of Computer Science \\ University of Bern \\ Bern, Switzerland \\ matthias.stuermer@inf.unibe.ch
}

\begin{abstract}
Sustainable procurement requires organizations to align their purchasing behavior with regard to broader goals linked to resource efficiency, climate change, social responsibility and other sustainability criteria. The level of sustainability in Information and Communication Technology (ICT) hardware procurement is analyzed for two reasons: First, ICT hardware belongs to the six key product groups in sustainable procurement. Second, ICT in general is expected to be an important enabler for low-carbon economies, providing solutions to reduce Green-House Gas (GHG) emissions. While the advantages of sustainable procurement are obvious, certain barriers hinder the adoption in day-to-day procurement. This case study on ICT hardware discusses the three important barriers "lack of clear definitions per product group", "missing market intelligence about sustainable products" and "inflexible procedures and attitudes as barriers for innovative approaches" based on an in-depth analysis of sustainable procurement of ICT hardware by the public sector in Switzerland. To this end, tender data published on the national procurement platform simap.ch is screened for sustainability criteria using the Common Procurement Vocabulary (CPV) nomenclature to identify relevant ICT projects. The results reveal to which extent such criteria as well as their determinants are currently included in public tenders. Using two different approaches, only a small number of tenders were found containing sustainability criteria of a wide range from basic to comprehensive. The overall performance of Swiss public procurement is benchmarked by comparing the identified sustainability criteria with available criteria from international key actors in sustainable procurement. Thus, this analysis provides novel insights on how public agencies today take sustainability into account when procuring ICT hardware.
\end{abstract}

Permission to make digital or hard copies of part or all of this work for personal or classroom use is granted without fee provided that copies are not made or distributed for profit or commercial advantage and that copies bear this notice and the full citation on the first page. Copyrights for third-party components of this work must be honored. For all other uses, contact the Owner/Author. ICT4S2020, June 21-26, 2020, Bristol, United Kingdom

(C) 2020 Copyright is held by the owner/author(s).

ACM ISBN 978-1-4503-7595-5/20/06.

https://doi.org/10.1145/3401335.3401352

\section{CCS CONCEPTS}

- Social and professional topics Professional topics Computing industry $\sim$ Sustainability $\bullet$ Hardware $\sim$ Power and energy Impact on the environment - Information systems $\sim$ Data management systems $\sim$ Data structures $\sim$ Data access methods Data scans - Hardware Power and energy Power estimation and optimization Enterprise level and data centers power issues - Social and professional topics User characteristics Geographic characteristics • Computing methodologies Machine learning • Information systems $\sim$ Data management systems $\sim$ Database design and models

\section{KEYWORDS}

ICT hardware, sustainable procurement, low-carbon economies, Life-Cycle management, Common Procurement Vocabulary

\section{ACM Reference format:}

Tobias Welz, Matthias Stuermer. 2020. Sustainability of ICT hardware procurement in Switzerland: A status-quo analysis of the public procurement sector. In Proceedings of ICT for Sustainability, $7^{\text {th }}$ International Conference, ICT4S 2020, June 21-26, 2020, Bristol, United Kingdom. ACM, New York, NY, USA, 12 pages.

https://doi.org/10.1145/3401335.3401352

\section{INTRODUCTION}

According to the World Bank 9.5 trillion USD are spent globally per year to promote sustainability [23]. This demonstrates the global economic importance of sustainable public procurement. In the European Union (EU) annual government expenditures on works, goods and services account for roughly 2.0 trillion USD, representing $14 \%$ of EU's GDP [10]. In the same field the Swiss federal administration alone spent 5.7 billion USD in 2018 [2]. These expenditures reflect the purchasing power of public procurement agencies and their obligation for important contributions towards local, regional, national and international sustainability goals.

In fact, Information and Communication Technology (ICT) hardware turns out to be one of the six most important product categories in private and public sustainable procurement [7] and according to United Nations (UN) Environment sustainability of ICT hardware procurement ranks as number one priority with 
national governments worldwide [24]. ICT hardware for basic dayto-day operations is often the most prioritized product category considered by public procurement agencies and is often purchased centrally.

Since ICT equipment is ubiquitously used global demand and corresponding environmental and social impacts are high. Consequently, it is important to consider life-cycle aspects in case of procurement [11]. Sustainability criteria in ICT hardware procurement are ranked "basic" if e.g. only energy consumption and corresponding Green-House Gas (GHG) emissions are taken into account. On the other hand facing global challenges in sustainable procurement demands a "comprehensive" approach like ecological criteria focusing on GHG emissions throughout the life-span, abiotic mineral depletion in the manufacture- and usephases, economic life-span optimization of ICT equipment using concepts of total cost of ownership (TCO) or life-cycle costing (LCC), as well as addressing social criteria on child labor and workers' safety [4].

In order to discuss environmental effects of ICT in particular, we first look at the general context of the climate debate. The term sustainability is here equated with the goals of the Paris Climate Treaty of 2015 (COP-21) [26]. The Intergovernmental Panel on Climate Change (IPCC) [17] has published a special report on what needs to happen to achieve its goals, i.e. calling for a switch to $100 \%$ renewable energy in the areas of buildings, transport and power supply to comply with global $\mathrm{CO}_{2}$ reduction targets by 2050 .

To understand the scope of the problem, in 2015 global ICT energy consumption [13] amounted to 2300TWh. In 2018 this had risen to $3000 \mathrm{TWh}$ corresponding to $2000 \mathrm{Mt} \mathrm{CO}_{2}$ or $4 \%$ of global GHG emissions, the same amount as all civil aviation. If this development continues, ICT will cause $8 \%$ of global GHG emissions in 2025 comparable to global car emissions. So ICT would become the fourth most important environmental impact.

Today, $45 \%$ of ICT energy consumption goes to producing new equipment and 55\% to using existing equipment [13]. Taking a closer look at the use-phase end-consumer devices in 2017 accounted for $20 \%$ (400Mt $\mathrm{CO}_{2}$ ) and data traffic for $35 \%$ (700Mt $\mathrm{CO}_{2}$ ) (data centers $19 \%$, network transmission $16 \%$ ) of global ICT energy consumption. From 2017-2022 the cumulated annual growth rate (CAGR) of the demand for new ICT equipment [6] is expected to be about $10 \%$. To complete the picture, Smartphone demand will grow 9\% CAGR with over 6 billion devices in use by 2022, as will be 1.2 billion Personal Computers (PC) and 0.79 billion Tablet Computers. In general, networked ICT devices will almost double between 2017-2022, with the number of machine-tomachine interfaces (M2M) rising sharply and PCs becoming slightly less important.

On average a Swiss consumer in 2015 caused $14 \mathrm{t} \mathrm{CO}_{2}$ of which $7 \mathrm{t}$ were actually emitted in Switzerland. The remaining part was released abroad, mainly by foreign production [14]. So total Swiss GHG emissions amounted to $95 \mathrm{Mt} \mathrm{CO}_{2}$ while the domestic emissions accounted for 48Mt. To comply with the global climate treaty, domestic $\mathrm{CO}_{2}$ emissions of 54Mt in 1990 must be reduced

\footnotetext{
${ }^{1}$ So far, worldwide material consumption reached 92.1 billion tons in 2017, up from
} 87 billion in 2015 and a 254 per cent increase from 27 billion tons in 1970 [27]. by $40 \%$ till 2030 , i.e. to $32 \mathrm{Mt}$. An ambitious scenario by swisscleantech [1] breaks down necessary GHG reductions to: buildings $-68 \%$, transport $-68 \%$, industry $-48 \%$, agriculture $-24 \%$, and waste disposal $-6 \%$. Mitigation of foreign emissions is demanded $-20 \%$ by 2030 .

Illustrating the current status of GHG emissions caused by ICT in Switzerland, a study by Hilty and Bieser [16] calculated domestic $\mathrm{CO}_{2}$ emissions of $2.55 \mathrm{Mt}$ in 2015 where $0.84 \mathrm{Mt}$ originated from infrastructure and $1.71 \mathrm{Mt}$ from end-user devices. This represented $5.3 \%$ of domestic GHG emissions which was above the global average of $4 \%$.

As stated by the UN International Resource Panel ICT is a keytechnology for decoupling natural resource use ${ }^{1}$ and environmental impacts from economic growth [25]. In the Swiss context, Hilty and Bieser pointed out decoupling opportunities using ICT towards a low-carbon economy by 2025. This goal requires overall domestic emissions to be reduced by $10.6 \mathrm{Mt} \mathrm{CO}_{2}$. Three scenarios on the mitigation of $\mathrm{CO}_{2}$ emissions are elaborated. The pessimistic version assumes an increase of domestic emissions from ICT growth up to $2.83 \mathrm{Mt}(+8 \%)$ and annual decoupling potentials through ICT use of only $0.72 \mathrm{Mt}$. The expected scenario assumes ICT to cause $2.40 \mathrm{Mt}$ (-6\%) with a decoupling potential of $2.79 \mathrm{Mt}$. The optimistic scenario claims $2.08 \mathrm{Mt}(-17 \%)$ with an annual decoupling potential of $6.99 \mathrm{Mt}$ in other industries. So, according to those scenarios the contribution of ICT to the required reduction of GHG emission for Switzerland would only contribute $2 \%, 16 \%$ or at maximum $49 \%$.

As shown in the Swiss scenario, ICT can initiate decoupling potentials within the use-phase of certain product groups towards a low-carbon economy. However, with global ICT energy demand expanding rapidly such gains could easily backfire ${ }^{2}$. In fact, the manufacture-phase of ICT equipment is already causing essential environmental and social burden.

In view of this problem public ICT procurement can play an important role by striving for contributions towards more sustainability in two directions. First sustainable ICT hardware infrastructure must be procured. Second ICT should be used for decoupling in other sectors according to their mitigation targets e.g. for buildings, transport and agriculture. In our study the focus lies on the acquisition of sustainable infrastructure. Decoupling opportunities are mentioned where possible e.g. using life-cycle costing.

Especially in Switzerland, where ICT emissions are above global average, it is obvious that the public administration should establish comprehensive sustainability approaches regarding ICT procurement while simultaneously recognizing its role as an important lever towards national sustainability goals.

\section{LITERATURE}

Several national and international agreements on sustainable procurement are essential for this case study. Most general the UN 2030 Agenda for Sustainable Development drafted in 2015 is

${ }^{2}$ Backfire stands for negative rebound effects through overcompensation of realized GHG savings. 
applicable with its 17 sustainable development goals (SDG) [28]. Especially SDG 12 (Ensure sustainable consumption and production patterns) as well as SDG 8 (Promote sustained, inclusive and sustainable economic growth, full and productive employment and decent work for all) deal with the concept of sustainable procurement:

- $\quad 12.7$ promote public procurement practices that are sustainable, in accordance with national policies and priorities.

- $\quad 8.4$ Improve progressively, through 2030, global resource efficiency in consumption and production and endeavor to decouple economic growth from environmental degradation, in accordance with the 10 Year Framework of Programmes on Sustainable Consumption and Production, with developed countries taking the lead.

The need for progress towards Goal 12 was underscored by data in the report of the Secretary General of the UN [27]: worldwide material consumption had reached 92.1 billion tons in 2017, up from 87 billion in 2015 when the goal was formulated, with the rate of extraction accelerating every year since 2000. Without urgent and concerted political action, as e.g. setting up sustainable public procurement strategies, global resource extraction could grow to 190 billion tons by 2060 .

To foster political actions UN Environment initiated a 10 Year Framework of Programmes on Sustainable Consumption and Production Patterns (10 YFP) in 2015 [29] consisting of six programs of which one is dedicated explicitly to sustainable procurement. As 10 YFP aims to foster national action plans it is recognized that especially European countries are working to embed sustainable procurement within environmental, social, and innovative policies providing some of the best examples of good sustainable public procurement (SPP) practices [24].

- 10 YFP - 10 Year Framework on Sustainable Consumption and Production Patterns

ISO 20400 establishes a sustainable procurement framework, addressing all kinds of organizations because every organization has environmental, social and economic impacts [18]. This framework gives key advice on how to strategically establish sustainable procurement within an organization.

\section{- $\quad$ ISO 20400:2017 Sustainable Procurement - Guidance}

Most member states of the European Union (EU) have approved national sustainable public procurement action plans that follow policy recommendations from the European Commission as in [24]. From 2012, new directives by the EU have intended to ensure greater inclusion of common sustainability goals in procurement processes. These goals include environmental protection, social responsibility, innovation, combating climate change, employment, public health and other social and environmental considerations, as provided in the 7th Environment
Action Programme (EAP) in 2013 [12] and stated in the EU public procurement directives.

- Directive 2014/23/EU the Concessions Directive

- Directive 2014/24/EU the Public Sector Directive

- Directive 2014/25/EU the Utilities Sector Directive

The above postulated EU requirements are reviewed for echoes in scientific literature and by key actors in SPP regarding examined obstacles, needs and trends. Therefore, the works of Sönnichsen and Clement [21], Marrucci, Daddi and Iraldo [20], as well as Cheng, Appolloni, D’Amato and Zhu [5] were examined as well as UN Environment [24], EU Green Public Procurement [10], and ICLEI - Local Governments for Sustainability [7].

As a result it appears to be, unfortunately, not so easy for public agencies to embrace their duties of exemplarity and responsibility to enact change, despite increased flexibility allowed by national action plans. They often go a long way to include social and environmental criteria in public contracts. But once included they only address product functionalities, rather than the practices of the suppliers of those products. To make a real change, it is crucial to recognize not just product functionality but the impact of the entire product life-cycle and look deeper into the supply chain to consider environmental, ethical and fair business practices. Moreover, public procurement agencies must have the ability to verify that contract provisions are respected which is impossible just via contract clauses or supplier codes of conduct alone. A "check the box" approach is insufficient and it is time to go beyond the status quo and adopt the above-mentioned approach regarding a sustainable supply chain. In order to meet the policy requirements of organizations monitoring and measuring sustainable procurement activities is crucial. At the same time such a monitoring would reveal the variety of these activities. Preconditions to enable sustainable public procurement are political mandates, a professional procurement team as well as knowledge of the financial efficiency of sustainable alternatives.

In Switzerland the federal administration has adopted the Agenda 2030. It is applied in different roles taken by central and decentralized federal agencies based on responsible entrepreneurial behavior as employer, investor, and procurer [3]. Thus the federal administration has accepted the duty of exemplarity and is perceived in this role by cantons and municipalities. The revision of the federal public procurement law in 2019 explicitly requires the integration of sustainability criteria in public procurement. This is fundamental for the policy requirements outlined above. With regard to the implementation of sustainability criteria into day-today procurement a handbook on sustainable procurement has been published as guide for procurers [4]. It gives guidelines for 19 product groups, nine of which have the highest priority rating 
ICT hardware CPV groups

\begin{tabular}{|c|c|c|c|c|c|}
\hline $\begin{array}{c}\text { Number of } \\
\text { entries }\end{array}$ & & $\begin{array}{c}\text { Number of } \\
\text { entries }\end{array}$ & & $\begin{array}{c}\text { Number of } \\
\text { entries }\end{array}$ & \\
\hline 221 & Personal Computer & 238 & Server & 86 & Smartphone \\
\hline 214 & 30213 & 160 & 48820 & 12 & 32236 \\
\hline 57 & 30213000 Personal computers & 69 & 4882000 Servers & 12 & 32236000 Radio telephones \\
\hline 63 & 30213100 Portable computer & 25 & 4882100 Network servers & 33 & 32252 \\
\hline 63 & 30213200 Tablet computer & 40 & 4882200 Computer servers & 21 & 32252000 GSM telephones \\
\hline 29 & 30213300 Desktop computer & 8 & 4882300 File servers & 6 & 32252100 Hands-free mobile telephones \\
\hline 2 & 30213500 Pocket computers & 15 & 4882400 Printer servers & 6 & 32252110 Hands-free telephones (wireless) \\
\hline 7 & 30212 & 3 & 4882500 Web servers & 41 & 64212 \\
\hline 5 & 30212000 Minicomputer hardware & 78 & 30211 & 41 & 64212000 Mobile-telephone services \\
\hline 1 & $30212100 \mathrm{CPU}$ for minicomputers & 11 & 30211000 Mainframe computer & & \\
\hline \multirow[t]{4}{*}{1} & 30211400 Computer configurations & 3 & 30211100 Super Computer & 64 & Fixed line device \\
\hline & & 13 & 30211400 Computer Configurations & 42 & 32552 \\
\hline & & 25 & 30211200 Mainframe hardware & 34 & 32552100 Telephone sets \\
\hline & & 25 & 30211300 Computer platforms & 8 & 32552110 Cordless telephone sets \\
\hline 89 & Computer Monitors & 1 & 30211500 Central processing units & 22 & 64215 \\
\hline 8 & 38652 & & & 22 & 64215000 IP telephone services \\
\hline 1 & 38652000 Cinematographic projectors & 170 & Printer & & \\
\hline 2 & 38652100 Projectors & 170 & 30232 & & \\
\hline 5 & 38652120 Video projectors & 23 & 30232000 Peripheral equipment & & \\
\hline 81 & 30231 & 73 & 30232100 Printers and plotters & & \\
\hline 25 & 30231000 Computer screens and consoles & 44 & 30232110 Laser printers & & \\
\hline 29 & 30231300 Display screens & 8 & 30232130 Colour graphics printers & & \\
\hline 18 & 30231310 Flat panel displays & 12 & 30232150 Inkjet-printers & & \\
\hline 9 & 30231320 Touch screen monitors & 10 & 30232700 Central controlling unit & & \\
\hline
\end{tabular}

Figure 1: ICT hardware CPV groups - identification of relevant product group clusters.

regarding sustainability. ICT hardware is one of these product groups. In general ICT hardware is one of the most important product groups in national and international public procurement activities in view of sustainability criteria.

\section{METHOD}

Although the advantages of sustainable procurement are clear, certain barriers hinder the adoption in day-to-day procurement like "lack of clear definitions per product group", "missing market intelligence to get to know about sustainable products” as well as "inflexible procedures and attitudes to opening-up to innovative approaches” [7].

The following analysis addresses the above mentioned barriers for sustainable public procurement of ICT hardware in Switzerland. The first challenge is to get access to information about public tenders. In Switzerland public procurement tenders are usually published on the Swiss electronic tendering platform simap.ch. Because the simap.ch service was established in 2009, our research center has developed a unique data platform, IntelliProcure, for consulting large-scale public procurement notices from 2009 as well as tender documents from 2017 on enabling market intelligence for Swiss public procurement for these time spans.

As of April 2020, the data platform IntelliProcure provides access to more than 70'000 tenders, 420'000 documents (1.4 TB), 4'000 public procurement agencies, and 15'000 suppliers. The wide range of data records also provides opportunities for data refinement. Machine-learning techniques like Elasticsearch [19] can be applied to provide a full-text search for all documents.
Together with other Open Source Software a data platform with a high level of data transparency is provided. The procedure accessing this data frame is described by Stuermer, Krancher and Myrach [22].

The simap.ch data set assigns all tenders to appropriate product groups in order to comprise all kinds of goods and services. For this classification the Common Procurement Vocabulary (CPV) in its latest version from 2008 [9] is used. The purpose of CPV is to standardize the terms used by contracting authorities to describe the subjects of contracts. These standard codes promote transparency and also set up an information system for public procurement. The CPV code is structured as an 8-digit number representing a hierarchy of categories as shown in the following example:

- 30000000 - Office and computing machinery the first 2-digits 30 represent CPV-Division

- 30200000 - Computer equipment and supplies the 3rd-digit 2 represents the CPV-Group

- 30210000 - Data-processing machines (hardware) the 4th-digit 1 represents the CPV-Class

- 30213000 - Personal computers the 5th-digit 3 represents CPV-Category

- 30213100 - Portable computers the 6th-digit 1 represents CPV-Sub-category

In a study by Grandia and Kruyen [15] the Belgian public procurement set of data records was screened for sustainability criteria. Analyzing tenders from 2011 to 2017 tender notifications as well as tender documents were screened at the level of CPV- 


\begin{tabular}{|c|c|c|c|c|c|}
\hline \multirow[t]{2}{*}{ ICT hardware product groups } & \multirow{2}{*}{$\begin{array}{c}\text { Number of tender } \\
\text { (2018-2019) }\end{array}$} & \multicolumn{4}{|c|}{ Public procurement agencies } \\
\hline & & $\begin{array}{l}\text { Central federal } \\
\text { agencies }\end{array}$ & $\begin{array}{l}\text { Decentral federal } \\
\text { agencies }\end{array}$ & $\begin{array}{l}\text { Cantonal } \\
\text { agencies }\end{array}$ & $\begin{array}{c}\text { Municipal } \\
\text { agencies }\end{array}$ \\
\hline $\begin{array}{l}\text { Personal Computer } \\
\text { total tender found }\end{array}$ & 61 & 1 & 1 & 26 & 33 \\
\hline tender including sustainabilty & 5 & 1 & 0 & 1 & 3 \\
\hline \multicolumn{6}{|l|}{ Server } \\
\hline total tender found & 43 & 2 & 1 & 32 & 8 \\
\hline tender including sustainabilty & 10 & 0 & 1 & 8 & 1 \\
\hline \multicolumn{6}{|l|}{ Smartphone } \\
\hline total tender found & 12 & 0 & 2 & 8 & 2 \\
\hline tender including sustainabilty & 2 & 0 & 0 & 0 & 2 \\
\hline Total & 116 & & & & \\
\hline
\end{tabular}

Figure 2: ICT hardware tenders containing sustainability criteria (2018-2019).

Division. The list of chosen sustainability criteria represents mostgeneral terms like e.g. "energy consumption" or "environmentally friendly”. As a result the numbers of found keywords were listed to describe the level of sustainability in a given category.

Extending the work of Grandia and Kruyen, the present study has developed a new approach for the retrieval of sustainability criteria on sector level or more differentiated in order to retrieve technique-specific or product-group specific criteria. This makes the distinction of "basic" and "comprehensive" sustainability approaches feasible to identify innovation potentials within a given product or service group. The procedure for the sectoral sustainability analysis is as follows:

1. Identification of relevant procurement areas using the CPV nomenclature.

2. Identification of calls for tender containing sustainability criteria for a given procurement period.

3. Classification of identified tenders into "basic" or "comprehensive" approaches.

4. Specification of the national level of sustainability based upon found criteria.

5. Evaluation of perceived level of sustainability compared to sector-specific standards as demanded by international key actors.

Before identifying ICT hardware tenders all ICT related CPV product groups were tagged based on a set of national [4] and international [7] [8] requirements, explicitly Personal Computers (Desktop Computer, Integrated Desktop Computer, Thin Client, Notebook Computer - including Tablet computer), Small-scale Servers, Computer Monitors - including projectors, Smartphones, Fixed line devices, as well as Printers for office purposes. Figure 1 shows all ICT hardware specific CPV groups and how often these categories were mentioned in the period 2009 - 2019.
The scope of our study is defined as follows:

- $\quad$ ICT hardware like Personal Computers (Desktop Computer, Integrated Desktop Computer, Thin Client, Notebook Computer - including Tablet Computer), Smallscale Servers, Computer Monitors - including Projectors, Smartphones, Fixed line devices, as well as Printers for office purposes.

- $\quad$ Swiss public procurement tenders in 2018 - 2019 found by screening tender notices and tender documents.

- $\quad$ Screening ICT hardware according to CPV groups as defined in Figure 1.

\section{RESULTS}

This chapter focusses on public procurement tenders for ICT hardware in 2018 and 2019. In line with the scope of our analysis as mentioned in chapter 3 the Swiss data set was screened for the three most important ICT hardware product groups "Personal Computer", "Server" and "Smartphone" because these product groups account for most of the increase in global ICT equipment. They also claim the largest share of global ICT energy demand, thus representing as predictor for environmental and social burden. The following analysis reflects the current state of public procurement in Switzerland for various types of procurement agencies.

\subsection{Identification of ICT hardware tenders containing sustainability criteria}

Applying the CPV categories defining ICT hardware (see Figure 1), tenders are screened manually for sustainability criteria. Figure 2 shows the number of tenders found for the three mentioned product categories.

In total 116 such tenders were identified, of which 17 contain sustainability criteria corresponding to a quota of $15 \%$. Looking at the product groups individually 5 of 61 tenders (8\%) for Personal 
Detailed overview of ICT tenders with sustainabiltiy criteria - Personal Computer (Examples)

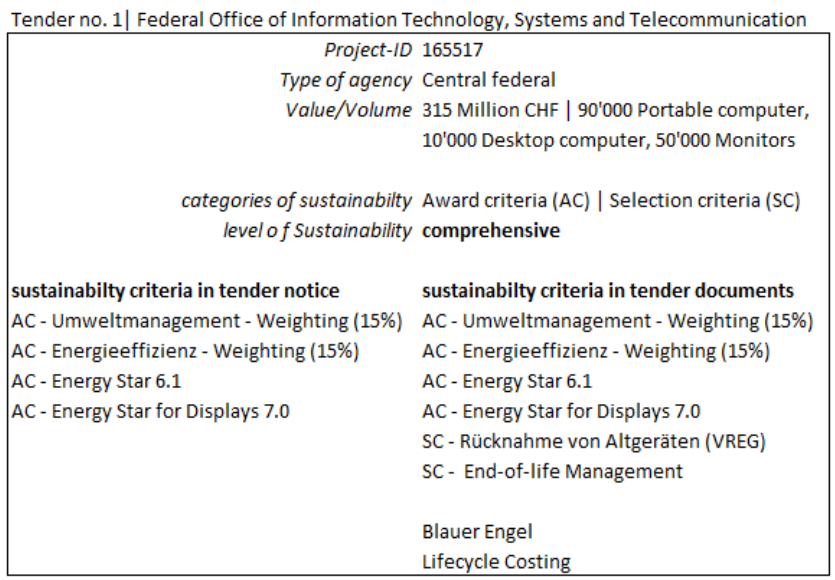

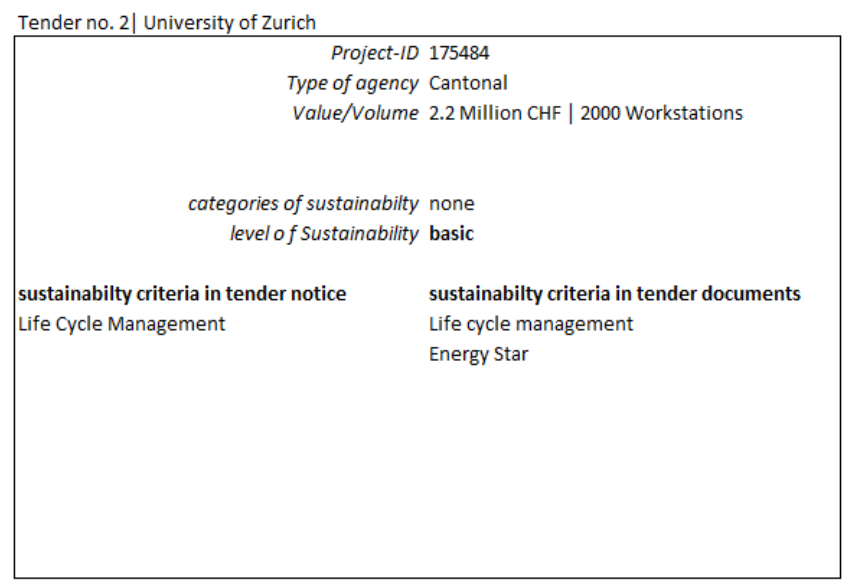

Figure 3: Overview of ICT tenders containing sustainability criteria - Personal Computer (2018-2019).

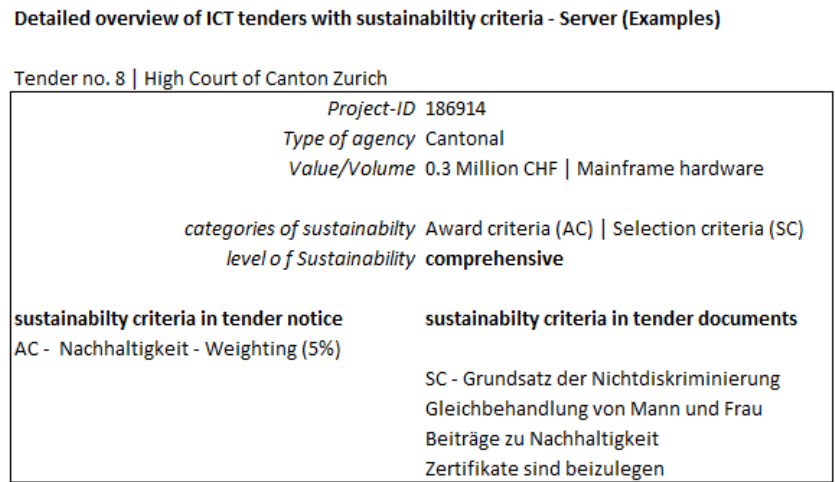

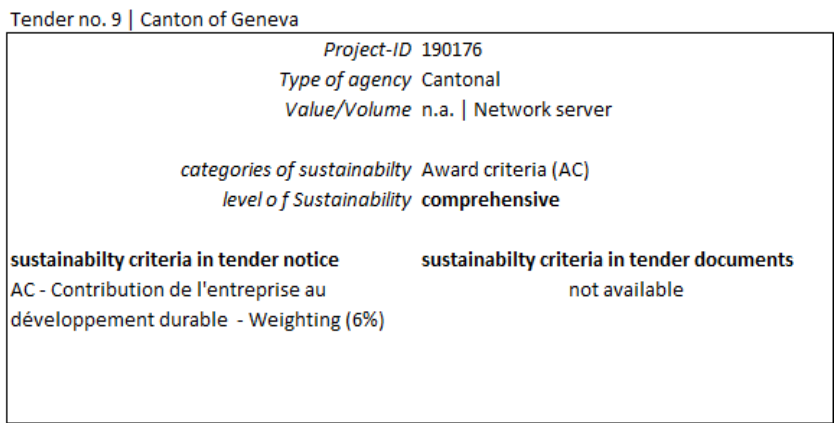

Figure 4: Overview of ICT tenders containing sustainability criteria - Server (2018-2019).

Computers, 10 of 43 (23\%) for Servers, and 2 of 12 (17\%) for Smartphones mention sustainability criteria.

From the point of view of procurement agencies cantonal authorities used sustainability criteria in 9 of 66 (14\%) projects while municipal authorities did so in 6 of 43 (14\%). Agencies on central and decentralized federal level appear quantitatively negligible due to the small number of tenders found.

However, the picture changes fundamentally when looking at the volume of acquisitions as well as the human resources managing public tenders. In the case of central and decentralized agencies, tenders are usually procured with large volumes and are managed by professional procurement teams. In contrast, cantonal procurement offices tend to procure medium-volume orders, while rather small tenders are issued on the level of municipalities, with fewer employees and less know-how available regarding sustainability. The product category "Personal Computer" shows that at the communal level it is mainly small and medium-sized tenders for workstations, school ICT and mobile clients that are procured, whereas at federal level only large tenders for workstations were found. The great number of tenders at the municipal level also reflects the need for consulting services because invitations for tenders are often formulated unspecific for the items to be procured.

\subsection{Extraction of sustainability criteria for Personal Computers, Servers and Smartphones}

In order to identify sustainability criteria all notifications for the respective tenders were screened, mainly tender notices and corresponding tender awards. In case sustainability criteria were discovered in these categories additional tender documents were examined.

A distinction was made for three categories of sustainability criteria: Award criteria (AC), Selection criteria (SC) and simple nominations. Award criteria indicate to which extent the category influences the award of the contract. The higher the weighting, the stronger the influence. Selection criteria are mandatory criteria that 


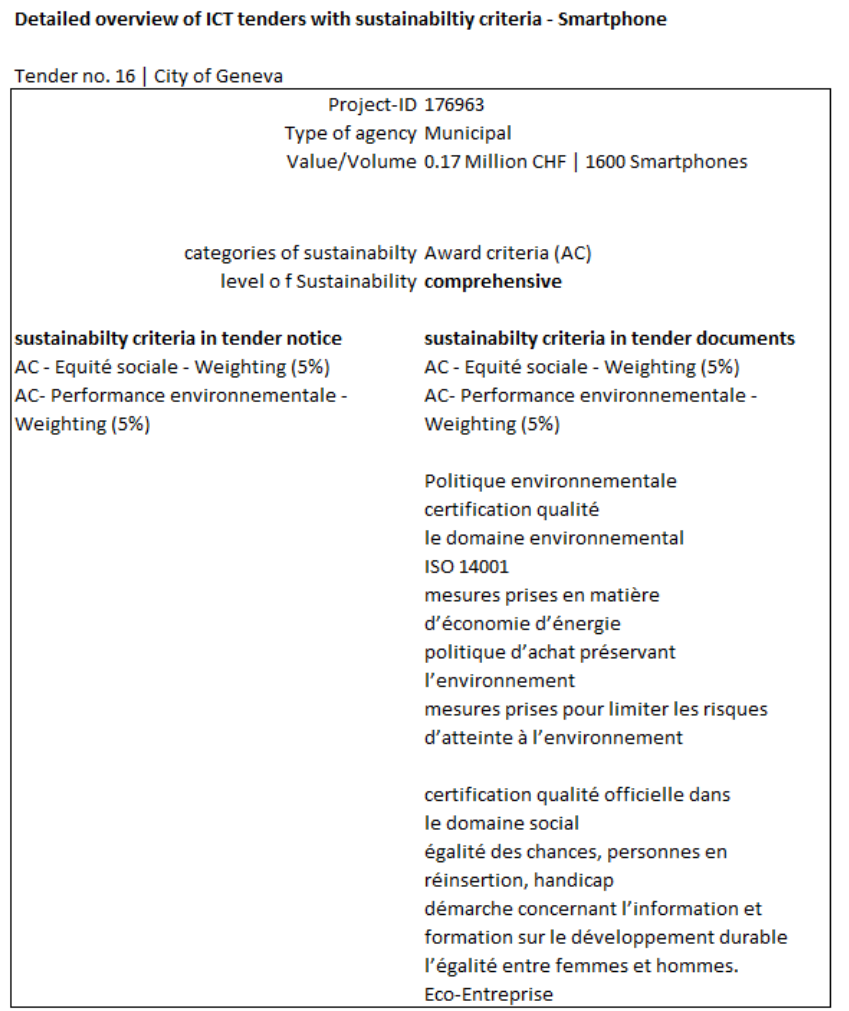

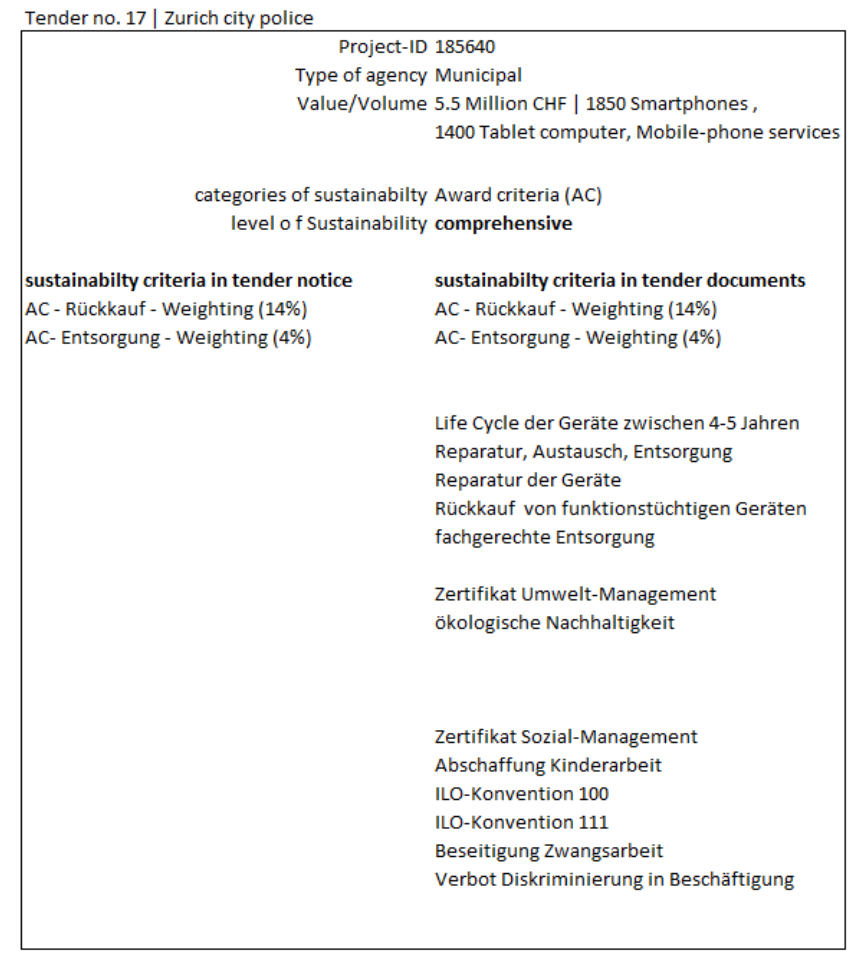

Figure 5: Overview of ICT tenders containing sustainability criteria - Smartphone (2018-2019).

must be fulfilled to evaluate the candidates' suitability. Simple nominations identify key words or phrases that can be part of award and selection criteria or simply comments helping to describe sustainability in more detail.

In order to better differentiate found sustainability criteria, general sustainability criteria and product-group specific sustainability criteria were distinguished. For orientation, several practical guides as in [7], [24], and [10] give further advice on the international context. Ref. [4] reflects the Swiss context. General sustainability criteria nominations ask for more than common practice or explicitly innovative approaches, e.g. proper disposal of goods according to the law is social consensus and therefore not recognized as sustainability criterion. Establishing recycling (closed loop resource use) or second-hand practices (reuse of products) on the other hand are recognized as sustainability criteria.

In case sustainability criteria are recognized in award and selection criteria, this is considered a "comprehensive” approach. On the other hand, sustainability criteria which are only loosely mentioned without influencing the decision reflect a "basic" approach.

Figure 3 - 5 show all sustainability criteria found for each of the three ICT hardware product groups. As detailed above (Figure 2) 17 tenders were identified containing ecological and social criteria, of which six tenders with a "basic" approach and eleven with a "comprehensive" approach. As displayed, sustainability criteria were identified for the French as well as for the Germanspeaking areas of Switzerland. No tenders containing sustainability criteria were found in the Italian-speaking part of Switzerland. Recognizing sustainability criteria, whether basic or comprehensive, in the general tender notice, always led to further screening of attached tender documents, i.e., if e.g. a basic approach was found in the tender notice, the same terms were searched for in the attached tender documents as well as additional terms which better describe the perceived sustainability approach.

\subsection{Classification of sustainability criteria}

A classification of all sustainability criteria pertaining to the allocation of product-group-specific and general sustainability, leads to clusters of ecological and social criteria (see Figure 6 - 7). The terms are ordered ascending from general to specific sustainability criteria. In case of the ecological criteria the terms were further grouped into four different levels -generaltechnique-specific - ICT-specific - product-group-specific- ${ }^{3}$. Social criteria are not further clustered.

With this classification at hand it is possible to search for ICT hardware tenders for any given timeframe and also to decide between "basic" and "comprehensive” sustainability approaches.

\footnotetext{
${ }^{3}$ These clusters are only valid for the ICT hardware CPV groups defined in Figure 1.
} 


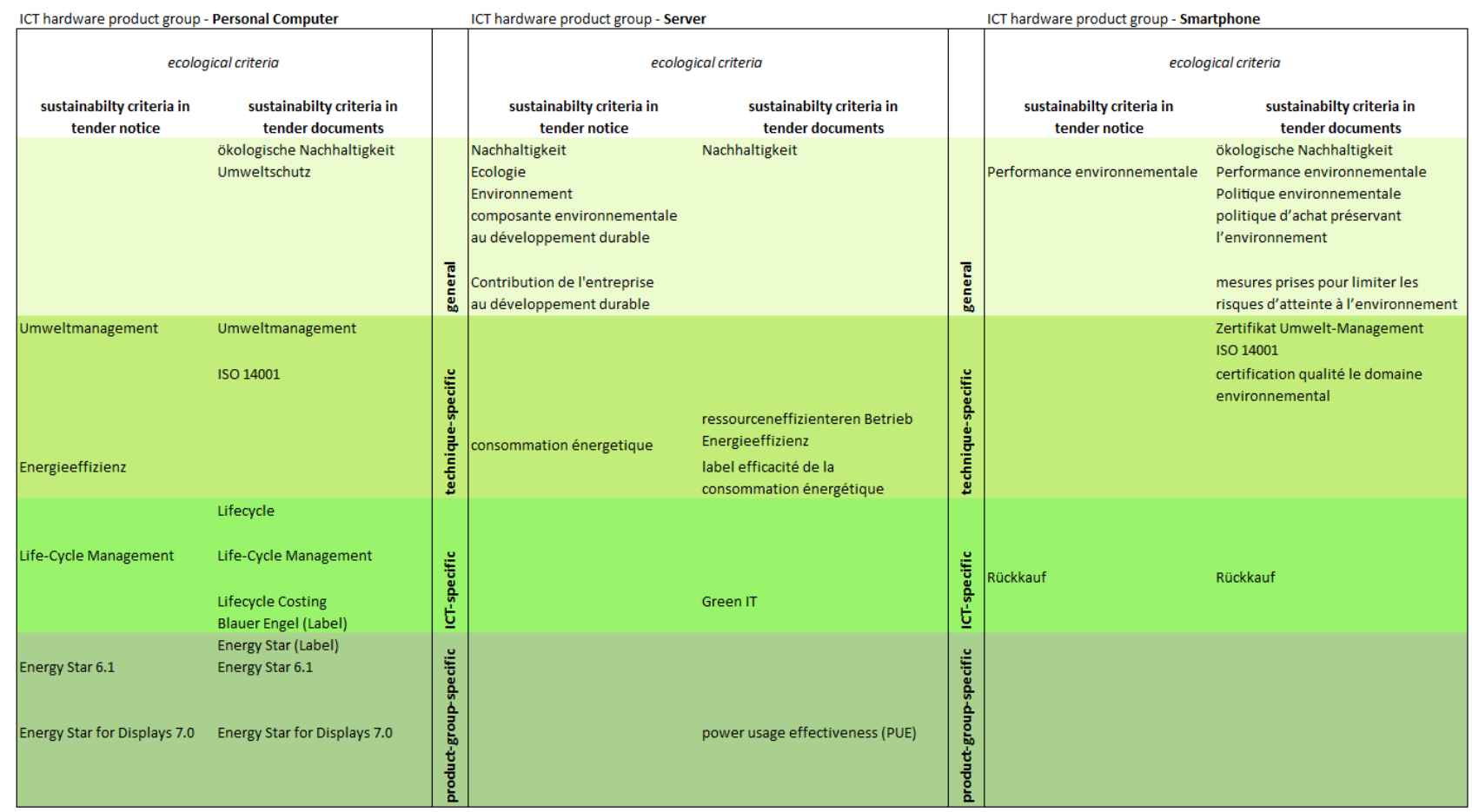

Figure 6: Overview of ecological criteria in ICT hardware product groups (2018-2019).

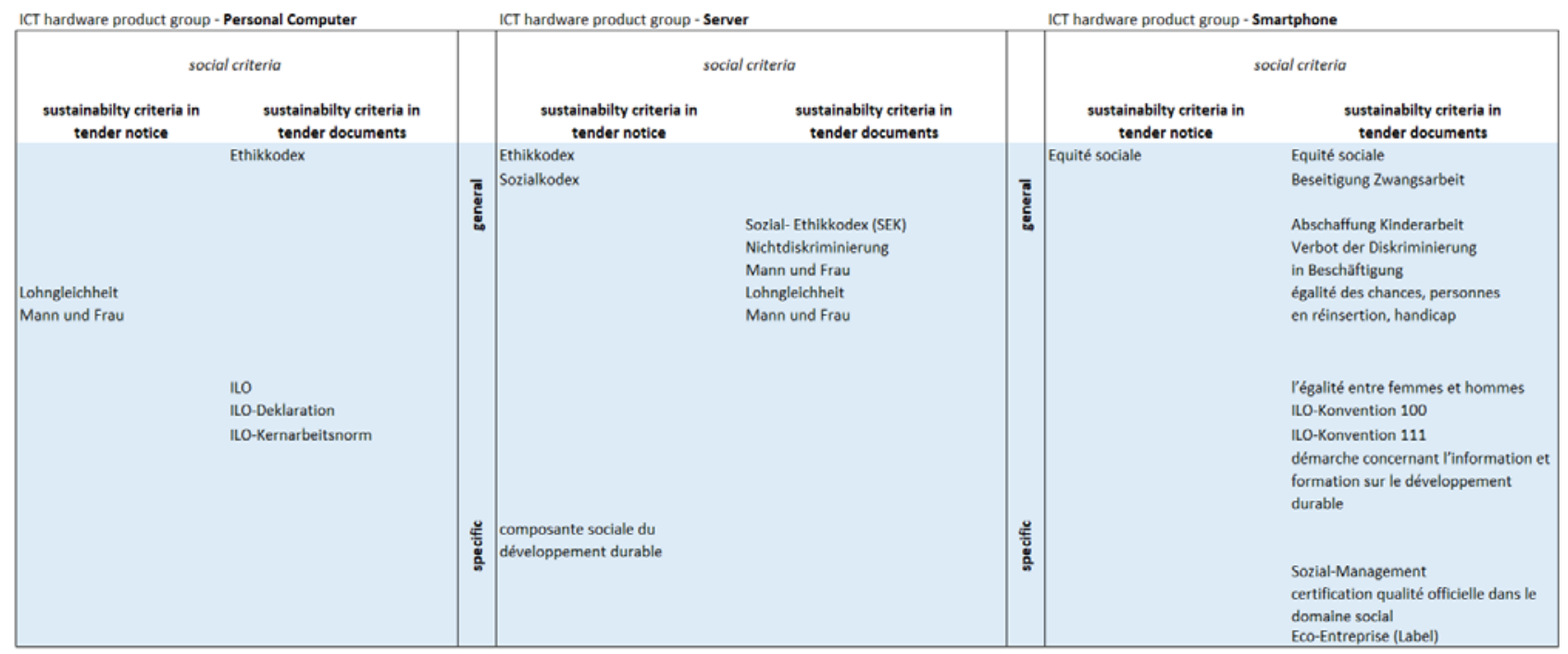

Figure 7: Overview of social criteria in ICT hardware product groups (2018-2019).

German and French sustainability criteria were merged and also translated into their respective English expressions (see Figure 8 - 9). With this list of sustainability keywords, it is possible to establish queries allowing to search for the content-wise presence of keywords of the respective clusters.

\subsection{Identification of ICT hardware tenders using a list of sustainability keywords and extending CPV range}

The in such a way identified sustainability criteria are used in a query screening the data frame to check if more ICT hardware tenders are found than by the manual selection. First, such a query 


\begin{tabular}{|c|c|c|c|c|}
\hline $\begin{array}{l}\text { ecological criteria in } \\
\text { German tender }\end{array}$ & $\begin{array}{l}\text { ecological criteria in } \\
\text { French tender }\end{array}$ & $\begin{array}{l}\text { ecological criteria in } \\
\text { English (translated) }\end{array}$ & & $\begin{array}{c}\text { ecological requirements by } \\
\text { key actors }\end{array}$ \\
\hline \begin{tabular}{|l|} 
Nachhaltigkeit \\
ökologische Nachhaltigkeit \\
Umweltschutz
\end{tabular} & $\begin{array}{l}\text { Ecologie } \\
\text { Environnement } \\
\text { Performance environnementale } \\
\text { Politique environnementale } \\
\text { politique d'achat préservant } \\
\text { I'environnement } \\
\text { composante environnementale } \\
\text { au développement durable } \\
\text { Contribution de l'entreprise } \\
\text { au développement durable } \\
\text { mesures prises pour limiter les risques } \\
\text { d'atteinte à l'environnement }\end{array}$ & $\begin{array}{l}\text { sustainability } \\
\text { ecological sustainability } \\
\text { ecology } \\
\text { environmental protection } \\
\text { environmental policy } \\
\text { environemtnal purchasing policy } \\
\text { environmental component } \\
\text { to sustainable development } \\
\text { Company's contribution to } \\
\text { sustainable development } \\
\text { measures to limit } \\
\text { environmental damage }\end{array}$ & שֶ & \\
\hline $\begin{array}{l}\text { Umweltmanagement } \\
\text { Zertifikat Umwelt-Management } \\
\text { ISO } 14001 \\
\text { ressourceneffizienteren Betrieb } \\
\text { Energieeffizienz }\end{array}$ & $\begin{array}{l}\text { certification qualité le domaine } \\
\text { environnemental } \\
\text { IsO } 14001 \\
\text { consommation énergetique } \\
\text { label efficacité de la } \\
\text { consommation énergétique }\end{array}$ & $\begin{array}{l}\text { environmental management } \\
\text { certified environmental management } \\
\text { ISo } 14001 \\
\text { resource-efficient operation } \\
\text { energy consumption } \\
\text { energy efficiency } \\
\text { energy efficiency label }\end{array}$ & 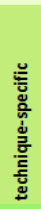 & $\begin{array}{l}\text { end of life management } \\
\text { low power mode }\end{array}$ \\
\hline $\begin{array}{l}\text { Energy Star (Label) } \\
\text { Energy Star } 6.1 \\
\text { Energy Star for Displays } 7.0 \\
\text { power usage effectiveness (PUE) }\end{array}$ & & $\begin{array}{l}\text { Energy Star (Label) } \\
\text { Energy Star } 6.1 \\
\text { Energy Star for Displays } 7.0 \\
\text { power usage effectiveness (PUE) }\end{array}$ & 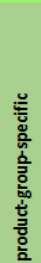 & $\begin{array}{l}\text { TCO Certified, generation } 8 \text { (Label) } \\
\text { Nordic Ecolabel 7.4 (Label) } \\
\text { Energy Star Computers 6.1 (Label) } \\
\text { Blue Angel UZ 78a (Label) } \\
\text { power usage effectiveness (PUE) } \\
\text { energy usage effectiveness (EUE) } \\
\text { NSF/ANSI 426-2018 (Label) } \\
\text { Energy Star Enterprise servers (Label) } \\
\text { Blue Angel UZ } 171 \text { (Label) } \\
\text { UL 110 Edition } 2 \text { (Label) } \\
\text { Blue Angel UZ } 106 \text { (Label) }\end{array}$ \\
\hline
\end{tabular}

Figure 8: Comparison of found ecological criteria with requirements by key actors in SPP (2018-2019).

\begin{tabular}{|c|c|c|c|c|}
\hline $\begin{array}{l}\text { social criteria in } \\
\text { German tender }\end{array}$ & $\begin{array}{l}\text { social criteria in } \\
\text { French tender }\end{array}$ & $\begin{array}{c}\text { social criteria in } \\
\text { English (translated) }\end{array}$ & & $\begin{array}{l}\text { social requirements by } \\
\text { key actors }\end{array}$ \\
\hline \begin{tabular}{|l} 
Ethikkodex \\
Sozialkodex \\
\\
Sozial- Ethikkodex (SEK) \\
Nichtdiskriminierung von \\
Mann und Frau \\
Beseitigung Zwangsarbeit \\
Verbot der Diskriminierung \\
in Beschäftigung
\end{tabular} & $\begin{array}{l}\text { Equité sociale } \\
\text { égalité des chances, personnes } \\
\text { en réinsertion, handicap }\end{array}$ & $\begin{array}{l}\text { Code of Ethics } \\
\text { Social Code } \\
\text { Social equity } \\
\text { Social Code of Ethics } \\
\text { Non-discrimination of men and women } \\
\text { Elimination of forced labor } \\
\text { Elimination of child labor } \\
\text { Non-discrimination in employment } \\
\text { Non-discrimination of disabeled people and } \\
\text { in rehabilitation }\end{array}$ & & 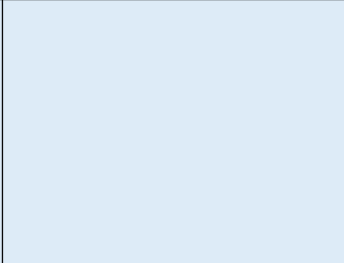 \\
\hline $\begin{array}{l}\text { Abschaffung Kinderarbeit } \\
\text { Lohngleichheit Mann und Frau }\end{array}$ & I'égalité entre femmes et hommes & $\begin{array}{l}\text { Equal pay for men and women } \\
\text { training on sustainable development }\end{array}$ & & living wage \\
\hline $\begin{array}{l}\text { ILO-Deklaration } \\
\text { ILO-Kernarbeitsnorm } \\
\text { ILO-Konvention } 100\end{array}$ & $\begin{array}{l}\text { démarche concernant l'information et } \\
\text { formation sur le développement durable }\end{array}$ & $\begin{array}{l}\text { ILO Declaration } \\
\text { ILO Convention } \\
\text { ILO Convention } 100\end{array}$ & 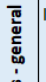 & ILO core standards \\
\hline $\begin{array}{l}\text { ILO-Konvention } 111 \\
\text { Sozial-Management }\end{array}$ & $\begin{array}{l}\text { composante sociale du } \\
\text { développement durable } \\
\text { certification qualité officielle dans le domaine } \\
\text { social } \\
\text { Eco-Entreprise (Label) }\end{array}$ & $\begin{array}{l}\text { ILO Convention } 111 \\
\text { social component of sustainable } \\
\text { development } \\
\text { social management } \\
\text { Eco-Entreprise (Label) }\end{array}$ & 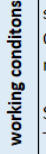 & $\begin{array}{l}\text { supplier code of conduct } \\
\text { Occupational health and safety } \\
\text { management systems (OHSMS) } \\
\text { Socially responsible public procurement } \\
\text { The LANDMARK project }\end{array}$ \\
\hline & & & 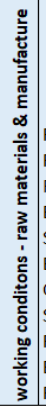 & $\begin{array}{l}\text { Responsible Business Alliance (RBA) } \\
\text { Responsible Labor Initiative (RLI) } \\
\text { Fair Labor Association (FLA) (Label) } \\
\text { Ethical Trading Iniative (ETI) (Label) } \\
\text { SA } 8000 \text { (Label) } \\
\text { Electronis Watch } \\
\text { Conflict minerals } \\
\text { Sustainable minerals } \\
\text { Responsible Minerals Initiative (RBMI) } \\
\text { Better Gold Initiative } \\
\text { Responsible Cobalt Initiative }\end{array}$ \\
\hline
\end{tabular}

Figure 9: Comparison of found social criteria with requirements by key actors in SPP (2018-2019). 
is performed for the CPV-range as defined in the scope in chapter 3. Then the grid is extended to the level of CPV-Class and CPVGroup.

In this way more ICT hardware tenders containing sustainability criteria were found. Within the same CPV-range three additional projects, at CPV-Class level four and at CPVGroup level fourteen further projects were identified.

\subsection{Comparison of sustainability criteria with sustainability requirements of key actors in SPP}

Assessing the level of sustainability, the detected criteria were compared to sustainability requirements by key actors in SPP as in [7], [10], and [8]. Figure 8 - 9 show on the left-side criteria retrieved from Swiss ICT hardware tenders and on the right-side requirements retrieved from SPP key actors [7], [10], [8]. For ecological criteria a large number of ICT-specific criteria match, even some keywords were additionally found in the tenders. Regarding the product-group-specific criteria some ICT-labels were mentioned in Swiss tenders, but the overall performance is rather low.

Examining social criteria Swiss tender perfectly match at the level of general working conditions but perform rather poorly for the specific sustainable criteria on working conditions for raw materials and in manufacture. Since no respective labels nor initiatives were found this particular area looks like a blind spot.

To sum up it can be stated, that with this study on ICT hardware it is possible to describe sustainability regarding ecological and social criteria on sector level. It is even possible to retrieve productspecific sustainability criteria to define a "comprehensive" sustainability level (see ICT-specific and product-group-specific criteria) for those product groups. In the case of ICT hardware, it can be stated that due to the characteristics of the products all our ecological criteria (Figure 8) as well as our social criteria (Figure 9) match with international sustainability criteria. This means that these criteria could be adopted for more than only the observed Swiss set of data records.

Thus it should be possible to use the procedure for the sectoral sustainability analysis as defined in chapter 3 to assess the level of sustainability for other sectors, like buildings, transport and agriculture.

In order to generalize our method it is to be examined to which extent this approach can be transferred to other sectors, dealing consistently with heterogeneous sustainability requirements. Taking e.g. buildings it can be stated that the level of sustainability in this sector represents a Swiss-specific set of sustainability criteria. This is due to the existence of several labels defining sustainability in a way specific for Swiss-administrational requirements. Appropriately formulated sustainability criteria for the building sector can only serve public procurement on state and sub-state level in Switzerland. A generalization of our method to procurement schemes of other nations is therefore only possible for sectors with sustainability criteria defined by international key actors and initiatives.

\section{CONCLUSIONS}

The particular study-design used in this work allows retrieving specific ICT hardware tenders for the Swiss data frame for a specified amount of product groups from several types of public procurement authorities. It is thus possible to retrieve tenders with distinguishable "basic" and "comprehensive" sustainability approaches as well as sustainability criteria (ecological and social) clustered from general to specific. In addition it is even possible for the ecological criteria to cluster them further into - general technique-specific - ICT-specific - product-group-specific criteria. Furthermore, in agreement with international key actors a list of keywords is obtained defining sustainability in respect to ICT hardware tenders encountered in day-to-day procurement. These keywords allow assessing sustainability criteria in ICT hardware at the overall level. Using appropriate queries and software even more tenders satisfying sustainability criteria could be found than by hand.

It is possible to use the analytical procedure demonstrated in this study to address other sectors of public procurement in order to retrieve sustainability criteria in general or assess the level of sustainability of tenders. It should be most effective to do this for buildings, transport and agriculture, because these sectors are crucial for achieving national climate goals.

While retrieving keywords for the building sector appears to be rather easy because of the high level of standardization the procedure could be rather complex for transport and agriculture. This is due to the great number of non-standardized sustainability criteria representing just individual cases than rather an entire sector. Transferring sectoral sustainability criteria to another country is also possible, but only if the retrieved criteria are applicable to international standards or requirements as in this special case of ICT hardware.

Beside the assessment of other sectors, it is also possible to examine the evolution of sustainability criteria over time using continually updated sustainability requirements.

The method of this particular study is limited by the requirement that specific queries are needed to address tender notices and tender awards. Specific queries are necessary to enable automatic screening of large data sets.

In the Swiss context, most retrieved tenders satisfy many general sustainability criteria but perform low on specific criteria, in particular meeting international standards. In general, sustainability criteria are found in less than $20 \%$ of all public tenders and the identified sustainability criteria vary from basic to comprehensive. Most ecologically comprehensive approaches were found in the German-speaking part while most comprehensive social approaches were found in the French-speaking part. Neither comprehensive nor basic sustainability approaches were found in the Italian-speaking part.

With regard to the level of know-how or professional procurement teams federal agencies perform best and municipal agencies worst. Closing this pre-procurement performance barrier is important for all sustainability goals. Apparently some agencies are pioneers with regard to sustainable procurement leading to high numbers of sustainability criteria being satisfied. 
Regarding the two levers of ICT in public procurement (sustainable ICT hardware and ICT for decoupling) the relevant sustainability criteria as well as approaches like life-cycle costing are well known, but apparently not widely used in day-to-day procurement.

Consequently, when it comes to the procurement of sustainable ICT hardware only sustainability criteria with regard to product functionalities are addressed. The second lever of ICT, decoupling or in particular life-cycle costing, is rarely considered. This low performance may be explained partly by the need for incorporation of such concepts in the organizations' sustainability strategy which is usually a rather complex undertaking.

It appears unfortunately not so easy for public agencies to embrace their duties of exemplarity and responsibility to enact change, even despite the existence of national public procurement action plans. To make a real change, it is crucial to recognize not just product functionality but the impact of the entire product lifecycle and look deeper into the supply chain to consider environmental, ethical and fair business practices. Preconditions to enable sustainable public procurement are political mandates, a professional procurement team as well as knowledge of the financial efficiency of sustainable alternatives.

Concluding, the present study aids in overcoming important barriers in public procurement: the lack of clarity is addressed through the definition of suitable CPV-groups, missing market intelligence is addressed through retrieval of sustainable tenders and inflexible approaches are addressed through retrieving bestpractice examples as well as sustainability criteria for basic and comprehensive approaches.

Thus the results contribute specific suggestions to practitioners on how to procure ICT hardware in public tendering. If the ecological and social criteria mentioned in the results are used more often in future public ICT procurement the hardware producers and vendors have strong incentives to adjust their products towards more sustainable solutions.

In addition, this study shows to researchers that it is possible to assess sustainability performance of public procurement on a sector level, in this case for ICT hardware, as well as to compare national levels of sustainability to international requirements. However, in order to benefit from these insights and to spread professional procurement know-how it is vital to establish a knowledge transfer throughout all levels of procurement agencies.

\section{ACKNOWLEDGMENTS}

This research is part of the National Research Project NRP 73 Sustainable Economy, Grant Number 407340_172351, and funded by the Swiss National Science Foundation.

\section{REFERENCES}

[1] Franziska Barmettler, Martina Novak, and Christian Zeyer. 2016. Pariser Klimaabkommen: Bedeutung für die Schweiz und die Wirtschaft [Paris Agreement: Importance for Switzerland and the economy]. swisscleantech, Zurich.

[2] Bundesamt für Bauten und Logistik. 2019. Beschaffungszahlungen 2018 [Procurement payments 2018]. Bundesamt für Bauten und Logistik (BBL), Bern.

[3] Bundesamt für Raumentwicklung. 2018. Corporate Social Responsibility (CSR) - Der Bund als Vorbild? [Corporate Social Responsibility (CSR) - The federal government as role model?]. Bundesamt für Raumentwicklung (ARE), Bern.
[4] Bundesamt für Umwelt. 2019. Relevanzmatrix - Orientierungshilfe für Beschaffende und Bedarfsstellen [Relevance matrix - orientation for procurers and public agencies]. Bundesamtes für Umwelt (BAFU), Bern.

[5] Wenjuan Cheng, Andrea Appolloni, Alessio D’Amato, and Qinghua Zhu. 2018. Green Public Procurement, missing concepts and future trends - A critical review. Journal of Cleaner Production 176, (March 2018), 770-784. https://doi.org/ 10.1016/j.jclepro.2017.12.027

[6] Cisco. 2019. Cisco Visual Networking Index: Forecast and Trends, 2017-2022. Cisco.

[7] Simon Clement, John Watt, and Abby Semple. 2016. The Procura+ Manual - A Guide to Implementing Sustainable Procurement (3rd ed.). ICLEI - Local Governments for Sustainability, European Secretariat, Freiburg.

[8] Nicholas Dodd, Candela Vidal-Abarca Garrido, Miguel Gama Caldas, Kathrin Graulich, Dirk Bunke, Rita Groß, Ran Liu, Andreas Manhart, and Siddharth Prakash. 2016. Revision of the EU green public procurement (GPP) criteria for computers and monitors. Publications Office of the European Union, Luxembourg.

[9] European Commission. 2007. Commission Regulation (EC) No 213/2008 of 28 November 2007 amending Regulation (EC) No 2195/2002 of the European Parliament and of the Council on the Common Procurement Vocabulary (CPV) and Directives 2004/17/EC and 2004/18/EC of the European Parliament and of the Council on public procurement procedures, as regards the revision of the CPV (Text with EEA relevance). Publications Office of the European Union, Luxembourg, 1-375. Retrieved February 10, 2020 from http://data.europa.eu/eli/ reg/2008/213/oj

[10] European Commission. 2016. Buying Green! A handbook on green public procurement (3rd ed.). Publications Office of the European Union, Luxembourg.

[11] European Commission. 2019. User Guide to the Life Cycle Costing Tool for Green Public Procurement of Computers and Monitors. Publications Office of the European Union, Luxembourg.

[12] European Parliament and Council. 2013. Decision No 1386/2013/EU of the European Parliament and of the Council of 20 November 2013 on a General Union Environment Action Programme to 2020 'Living well, within the limits of our planet' Text with EEA relevance. In Documents in European Community Environmental Law. Publications Office of the European Union, Luxembourg, 171-200. Retrieved December 19, 2019 from http://data.europa.eu/eli/dec/2013/ 1386/oj

[13] Hugues Ferreboeuf, Françoise Berthoud, Philippe Bihouix, Pierre Fabre, Daniel Kaplan, and Laurent Lefèvre. 2019. Lean ICT - Towards Digital Sobriety. The Shift Project.

[14] Rolf Frischknecht, Carsten Nathani, Martina Alig, Philippe Stolz, Laura Tschümperlin, and Pino Hellmüller. 2018. Umwelt-Fussabdrücke der Schweiz [Environmental Footprints of Switzerland]. Bundesamt für Umwelt (BAFU), Bern. Retrieved August 1, 2019 from www.bafu.admin.ch/uz-1811-d

[15] Jolien Grandia and Peter M Kruyen. 2017. Sustainable procurement: A big-data study into the level of sustainability of more than 140,000 published procurement contract notices by Belgian contracting authorities. Radboud Universiteit, Nijmegen. Retrieved April 17, 2018 from https://hdl.handle.net/2066/181464

[16] Lorenz M Hilty and Jan C T Bieser. 2017. Opportunities and Risks of Digitalization for Climate Protection in Switzerland. University of Zurich, Zurich.

[17] IPCC. 2018. Global Warming of $1.5^{\circ} \mathrm{C}$. An IPCC Special Report on the impacts of global warming of $1.5^{\circ} \mathrm{C}$ above pre-industrial levels and related global greenhouse gas emission pathways, in the context of strengthening the global response to the threat of climate change, sustainable development, and efforts to eradicate poverty. In Valérie Masson-Delmotte, Panmao Zhai, Hans-Otto Pörtner, Debra C Roberts, James Skea, Priyadarshi R Shukla, Anna Pirani, Wilfran Moufouma-Okia, Clotilde Péan, Roz Pidcock, Sarah Connors, Robin J B Matthews, Yang Chen, Xiao Zhou, Melissa I Gomis, Elisabeth Lonnoy, Tom Maycock, Melinda Tignor and Tim Waterfield (eds.). IPPC, 15-38.

[18] ISO 20400. 2017. Sustainable procurement - Guidance. International Organization for Standardization.

[19] Oleksii Kononenko, Olga Baysal, Reid Holmes, and Michael W Godfrey. 2014. Mining modern repositories with elasticsearch. In Proceedings of the 11th Working Conference on Mining Software Repositories - MSR 2014, ACM Press, Hyderabad, India, 328-331. https://doi.org/10.1145/2597073.2597091

[20] Luca Marrucci, Tiberio Daddi, and Fabio Iraldo. 2019. The integration of circular economy with sustainable consumption and production tools: Systematic review and future research agenda. Journal of Cleaner Production 240, (December 2019), 1-12. https://doi.org/10.1016/j.jclepro.2019.118268

[21] Sönnich Dahl Sönnichsen and Jesper Clement. 2020. Review of green and sustainable public procurement: Towards circular public procurement. Journal of Cleaner Production 245, (February 2020), 1-18. https://doi.org/10.1016/ j.jclepro.2019.118901

[22] Matthias Stuermer, Oliver Krancher, and Thomas Myrach. 2017. When the Exception Becomes the Norm: Direct Awards to IT Vendors by the Swiss Public Sector. In Proceedings of the 10th International Conference on Theory and 
Practice of Electronic Governance - ICEGOV '17, ACM Press, New Delhi AA, India, 43-46. https://doi.org/10.1145/3047273.3047329

[23] The World Bank. 2016. Despite progress, transparent and efficient government procurement rules remain a global challenge: WBG report. Retrieved December 19, 2017 from http:/www.worldbank.org/en/news/press-release/2016/12/05/ despite-progress-transparent-and-efficient-government-procurement-rulesremain-a-global-challenge-wbg-report

[24] UN Environment. 2017. Global Review of Sustainable Public Procurement. United Nations Environment Programme, Nairobi, Kenya.

[25] UNEP. 2011. Decoupling natural resource use and environmental impacts from economic growth. United Nations Environment Programme, Kenya, 1-150.

[26] United Nations. 2015. Paris Agreement. Paris.

[27] United Nations Economic and Social Council. 2019. Special edition: progress towards the Sustainable Development Goals. 1-39.

[28] United Nations General Assembly. 2015. Transforming Our World: The 2030 Agenda for Sustainable Development. In A New Era in Global Health, William Rosa (ed.). Springer Publishing Company, New York, NY. https://doi.org/ 10.1891/9780826190123.ap02

[29] United Nations General Assembly. 2015. Sustainable development: implementation of Agenda 21, the Programme for the Further Implementation of Agenda 21 and the outcomes of the World Summit on Sustainable Development and of the United Nations Conference on Sustainable Development. New York, NY, 1-7. 